\title{
Effect of Black Dates on Iron Deficiency Anemia of Orphanage Children
}

\author{
Heba Ezz El-Din Youssef and Abeer Ahamed Khedr \\ Nutrition and Food Sciences Department, Faculty of Home Economics, Minufiya University, \\ Shibin El-Kom, Egypt
}

Received on: $3 / 9 / 2015$

Accepted: $22 / 11 / 2015$

\section{ABSTRACT}

Iron deficiency anemia represents a major public health problem, particularly in infants, young children and pregnant women. Therefore, this study was aimed to evaluate the effect of black dates on children suffering from iron deficiency anemia living in orphanage. Forty male children (9-11years) were divided into four equal groups. Non-anemic group, anemic groups include positive control group, date with hulls group and date without hulls group (ingested $100 \mathrm{~g}$ black dates daily for 8 weeks). The energy, protein, carbohydrate, fat, fiber, vitamins and minerals intake of non-anemic and anemic groups compared with Dietary Reference Intakes (DRI) were evaluated. The anthropometric measurements and hematological parameters during the experiment period were also evaluated. Anemic groups did not consume enough protein however; energy and fiber were approximately similar to the DRI values. Non-anemic group and anemic groups had lower thiamin, vitamin A, vitamin E, calcium and phosphorus intake than DRI values. Iron and zinc was higher in non-anemic group compared with DRI values while anemic groups had an opposite trend. Date without hulls group had higher weight and body mass index than non-anemic group and date with hulls group. Hemoglobin, haematocrit, red blood cell, mean corpuscular volume, mean corpuscular hemoglobin, serum iron, serum ferritin and transferrin saturation in black date groups were increased by increasing the experiment period while total iron binding capacity had an opposite trend. Date without hulls group was more effective than date with hulls group in improving serum iron, serum ferritin, transferrin saturation and total iron binding capacity.

\section{Key words: Orphanage children, anemia, hemoglobin and dietary intake.}

\section{INTRODUCTION}

Iron-deficiency anemia is a worldwide public health problem, affect both developed and developing countries, with serious consequences to human health and the socio economic developmen of countries (Yurdakök et al., 2004). It affects approximately $30 \%$ of the world's population (Gasche et al., 2004). Although anemia has a variety of causes, anemia due to iron deficiency represents $50 \%$ of these causes (Black et al., 2003). The main risk factors for iron deficiency among young children are low intake and the high requirement of iron during child growth (Soliman et al., 2009 and Falkingham et al., 2010). Iron deficiency anemia develops when available iron is insufficient to support normal red cell production which is the most common type of anemia. Common causes of iron deficiency include inadequate intake of dietary iron, inadequate iron utilization during chronic and inflammatory diseases, impaired iron absorption, or excess iron loss (Santiage, 2012). Iron supplemen or an iron-fortified food with added micronutrients will have a beneficial effect on hemoglobin status in children at risk of micronutrient deficiencies (Rosado et al., 2010). Iron supplements are useful for production of a rapid improvement in the iron status in anemic individuals (Tang et al., 2015). Several substitutions are available for prevention and/or treatment of anemia. Rice fortification was an effective intervention strategy to correct iron deficiency in children under 5 years old (Hijar, et al., 2015). Ingestion of germinated fenugreek reduced anemia in children $6-8$ years old (E) Mancy, 2008). Therefore, this study was aimed to evaluate the effect of black dates with or without hulls as a plant source of iron on children suffering from iron deficiency anemia living in orphanage.

\section{MATERIALS AND METHODS}

Black dates were purchased from local market of Shibin El-Kom, Minufiya, Egypt

All ethical concerns required for human research have been considered before we start this research. Also, approvals from Faculty of Home Economic, Menufiya University, and Ministry of Solidarity as well as orphanage in Shibin El Kom, Egypt were received before conducting this research.

Subjects design

Eighty male children aged from 9-11 years were randomly selected from two orphanages at Shibin El-Kom, Minufiya, Egypt. At the beginning of experiment, a $5 \mathrm{ml}$ of their blood samples were collected to determine hemoglobin $(\mathrm{Hb})$, hematocrit $(\mathrm{Ht})$, red blood cell (RBC), serum iron (SI), serum ferritin (SF) and total iron binding capacity (TIBC). As the obtained data basis, forty children were 
divided into four equal groups. The first group was non-anemic group (negative control group), the second, third and fourth groups were anemic groups. The second group was positive control group (untreated), the third and the fourth anemic groups were given black dates with or without hulls (100g black date / daily for 8 weeks), respectively. Anemic groups were diagnosed as iron deficiency anemia with cutoff point of anemia indices less than $11 \mathrm{~g} / \mathrm{dl}$, $30 \mu \mathrm{g} / \mathrm{dl}$ and $27 \mathrm{fl}$ for hemoglobin, ferritin and mean corpuscular hemoglobin $(\mathrm{MCH})$, respectively. After 4 and 8 weeks, blood samples were collected to evaluate the hematological parameters. Anthropometric Measurements

Weight was measured to the nearest $0.1 \mathrm{~kg}$ with an electronic scale, children wore light clothes and without shoes. Children height was measured to the nearest $0.1 \mathrm{~cm}$. The body mass index (BMI) was calculated from the following equation: BMI $=$ weight $(\mathrm{kg}) \div$ square of height $(\mathrm{m})$

The mean height for age and BMI for age Zscores were compared to the WHO (2007) reference values.

Food intake was recorded for 3 days, including week end day and the previous or next 2 days (Wednesday, Thursday, Friday or Friday, Saturday, Sunday). Energy and nutrients intakes were calculated by using a computer program based on the food composition table (1996) of the National Institute of Nutrition. Results were compared with Dietary Reference Intakes (DRIs, 2003).

\section{Analytical Methods}

\section{Proximate chemical composition}

Moisture, fat, protein, ash, fiber and $\mathrm{Fe}$ of dates with and without hulls, were determined according to the method of AOAC, (1990). The carbohydrates were calculated by difference.

\section{Hematological parameters}

Hemoglobin $(\mathrm{Hb})$ red blood cell (RBC) and hematocrit $(\mathrm{Ht})$ of heparinized blood samples were measured using automated hematology analyze (Sysmex, Kobe, Japan).Mean corpuscular volume $(\mathrm{MCV})$, mean corpuscular hemoglobin $(\mathrm{MCH})$ and transferrin saturation (TS) were calculated by Lee and Nieman, (1996) according to the following equations:

$$
\begin{aligned}
& \mathrm{MCV}=\frac{\mathrm{Ht}}{\mathrm{RBC}} \times 10 \\
& \mathrm{MCH}=\frac{\mathrm{Hb}}{\mathrm{RBC}} \times 10 \\
& \mathrm{TS}(\%)=\frac{\mathrm{SI}}{\mathrm{TIBC}} \times 100
\end{aligned}
$$

\section{Statistical Analysis}

The experimental data were subjected to an analysis of variance (ANOVA) for a completely randomized design using a statistical analysis system SAS, (2000). Duncan's multiple range tests were used to determine the differences among means at the level of $95 \%$.

\section{RESULTS AND DISCUSSION}

Proximate chemical composition, iron and vitamin $\mathrm{C}$ contents of black dates with and without hulls are presented in Table (1). There were no significant $(\mathrm{P}>0.05)$ differences in moisture and carbohydrate between black dates with and without hulls. Black dates with hulls had higher $(\mathrm{P} \leq 0.05)$ fiber, ash, iron and vitamin $\mathrm{C}$ contents, while it had lower $(\mathrm{P} \leq 0.05)$ protein and fat contents as compared with black dates without hulls. El Shorbagey, (2012) reported that black date had high contents of protein $(9.94 \%)$, carbohydrate $(69.4 \%)$, fiber $(11.1 \%)$ and iron content $(166.5 \mathrm{mg} / 100 \mathrm{~g})$ (on dry basis) while, fat $(1.45 \%)$ was low. Al-Shahib and Marshall (2003) reported that the chemical composition of the dates were $44-88 \%, 0.2-0.5 \%, 2.3-5.6 \%$ and 6.4 $11.5 \%$ for carbohydrate, fat, protein and fiber, respectively. The date pulps are rich in iron, calcium, cobalt, copper, fluorine, magnesium, manganese, potassium (Al Farsi and Lee, 2008 and Mohamed and Khamis, 2004).

Energy and dietary macronutrients intake of non-anemic and anemic groups are shown in Table (2). No significant differences $\left(\mathrm{P}^{>} 0.05\right)$ were found in energy and carbohydrate between non-anemic and anemic groups. However, non-anemic group had a higher $(\mathrm{P} \leq 0.05)$ protein content than anemic group. The positive control group, date with hulls group and date without hulls group did not consume enough protein which less than mentioned in DRI by $29.47,7.53$ ant $9.15 \%$, respectively however, energy and fiber were approximately similar to the DRI values. In orphanage in Shibin El-Kom, Egypt the daily intake of energy and protein were lower than RDA values by 14.4 and $16.4 \%$, respectively (Hussein et al., 2006). However, El Gendy, (2000) reported that orphaned male in Minufiya, Egypt covered $69.47 \%$ and $100 \%$ of RDI from daily energy and protein intake.

The results showed that the percentage of energy distribution derived from carbohydrate, protein and fat were 79.2, 6.1 and $14.9 \%$, respectively for non-anemic children, 80.7, 4.2 and $14.9 \%$, respectively for positive group, $81.1,5.5$ and $13.6 \%$, respectively for date with hulls group and $79.2,5.4$ and $15.4 \%$, respectively for date without hulls group. The results also indicated that there was a tendency towards exclusive reliance on starches because they are bulky thus giving satiety value and cheap. Hussein et al., (2006) found that carbohydrate, protein and fat provided 55.54, 15.17 and $30.23 \%$ of total calorie, respectively for children living in orphanage. This difference may be due to the food eaten by children in orphanages 
mainly depends on aids which differ from time to time. 
Data in Table (3) show vitamins and minerals intake of non-anemic and anemic groups. Nonanemic group had higher $(\mathrm{P} \leq 0.05)$ thiamin, riboflavin, vitamin $\mathrm{A}$, vitamin $\mathrm{E}$, calcium, iron and zinc than anemic group, while phosphorus had an opposite trend. Non-anemic group and anemic group had a similar $(\mathrm{P}>0.05)$ vitamin $\mathrm{C}$. Anemic group intake date with or without hulls had higher $(\mathrm{P} \leq 0.05)$ calcium than positive control group however vitamin A had opposite trend. Groups intake date with or without hulls and positive control group had similar $(\mathrm{P}>0.05)$ thiamin riboflavin, vitamin $\mathrm{C}$ and phosphorus.

The mean intake of vitamin $\mathrm{A}$, vitamin $\mathrm{E}$, calcium and phosphorus for non-anemic group and anemic groups were lower than DRI values. The children in this study consumed inadequate of riboflavin, calcium and phosphorus, which are essential for carbohydrate use and essential for bone health, respectively. However, they consume adequate of vitamin $\mathrm{C}$, which is important for iron absorption, and skin health. The low intake of calcium and phosphorus might be due to the low consumption of milk in orphanages, which depends on community aid. Anemic children had lower iron and zinc (5.66- 5.96 and 5.95-6.29 mg/c respectively) than DRI value $(8 \mathrm{mg} / \mathrm{d})$. The mean iron and zinc values were lower than DRI values by (25.5 and $21.38 \%$ ) for positive group, (29.25 and $25.63 \%)$ for dated with hulls and (28 and $21.63 \%)$ for dates without hulls, respectively. Hussein et al. (2006) reported that the daily intake of vitamin A and $\mathrm{Ca}$ for orphanage children were lower than RD by 52.6 and $43.3 \%$, respectively. El Gendy, (2000) found shortage in calcium and magnesium intakes in Minufiya orphanage as compared with RDI.

Data in Table (4) show the anthropometric measurements of non-anemic and anemic groups There were no significant $(\mathrm{P}>0.05)$ differences in height and age between of non-anemic and anemic groups. Positive control group and date withou hulls group had higher $(\mathrm{P} \leq 0.05)$ weight and $\mathrm{BM}$ than non-anemic group and date with hulls group. On the other hand, no significant $(\mathrm{P}>0.05)$ differences were found in weight and BMI between non-anemic group and date with hulls group. Comparison to WHO (2007) reference values, height for Z-score (HAZ) and BMI for Z-score (BMI Z-score) values, the HAZ value refer to normal between 0 and $+1 \mathrm{SD}$ for all groups However BMI Z-score values refer to overweight between +1 and +2 SD for non-anemic and date with hulls groups and obese $>+2 \mathrm{SD}$ for positive control and date without hulls groups. This observation might be due to increase the carbohydrate intake and or decrease the physical activity. Karim and Zahid, (2012) reported that the HAZ for $89 \%$ of orphan children was normal and $21 \%$ was overweight in Dhaka city in Bangladesh. The classification of BMI in orphanage of Shibin El-Kom, Egypt reveals that $50 \%$ of male children were in normal weight (Hussein et al., 2006).

Table (5) shows the effect of black dates on the $\mathrm{Hb}, \mathrm{Ht}, \mathrm{RBC}, \mathrm{MCV}$ and $\mathrm{MCH}$ of non- anemic and anemic groups. The levels of $\mathrm{Hb}, \mathrm{Ht}, \mathrm{RBC}, \mathrm{MCV}$ and $\mathrm{MCH}$ in anemic groups were significantly $(\mathrm{P} \leq 0.05)$ lower than non-anemic group with the exception of MCV for anemic groups ingested black date for 8 weeks which was similar to $(\mathrm{P}>0.05)$ nonanemic group.

At zero time, $\mathrm{Hb}, \mathrm{Ht}, \mathrm{RBC}, \mathrm{MCV}$ and $\mathrm{MCH}$ in positive control group were similar $(\mathrm{P}>0.05)$ to anemic groups ingested black dates with or without hulls. However after 4 and 8 weeks, their levels in positive control group were significantly $(\mathrm{P} \leq 0.05)$ lower than anemic groups ingested black dates with or without hulls with exception of RBC for 8 weeks which was similar to $(\mathrm{P}>0.05)$ anemic groups ingested black dates. The results indicated that black dates enhanced $\mathrm{Hb}, \mathrm{Ht}, \mathrm{MCV}$ and $\mathrm{MCH}$ after 8 weeks of experiment period. These increments might be due to improve in iron intake of groups ingested black dates with or without hulls, which had a positive effect on hematological parameters. Abdel-Rahman et al., (2008) reported that the levels of $\mathrm{Hb}$ were improved in Egyptian childbearing females after ingesting $100 \mathrm{~g}$ daily black dates for 7 weeks. These results are in agreement with those of Hemandez et al., (2006) and Sazawal et al., (2010), who reported that increased $\mathrm{Fe}$ intake response with increment of $\mathrm{Hb}$ concentration.

There were no significant $\left(\mathrm{P}^{>} 0.05\right)$ differences in hematological parameters under study between date with hulls group and date without hulls group with the exception of $\mathrm{Ht}$ for date without hulls group for 8 weeks which was higher $(\mathrm{P} \leq 0.05)$ than date with hulls group for 8 weeks.

Table (6) shows the effect of black dates on SI, SF, TIBC and TS of non- anemic and anemic groups. Non-anemic children had higher $(\mathrm{P} \leq 0.05)$ SI, SF and TS than anemic children with the exception of SF for anemic children ingested date without hulls for 8 weeks which was similar to $(\mathrm{P}>0.05)$ non-anemic children. Anemic children had higher $(\mathrm{P} \leq 0.05)$ TIBC than non-anemic children during the experiment period.

At zero time, anemic children ingested black dates had higher $(\mathrm{P} \leq 0.05) \mathrm{SI}$ and $\mathrm{TS}$ than positive control group, while TIBC had an opposite trend. There was no significant $\left(\mathrm{P}^{\prime} 0.05\right)$ difference in $\mathrm{SF}$ between positive control group and date groups. As well as there were no significant $\left(\mathrm{P}^{\prime} 0.05\right)$ differences in SI, SF and TS between date with hulls 
group and date without hulls group. However, TIBC

in date with hulls group was lower $(\mathrm{P} \leq 0.05)$ than

date without hulls group. 
After 4 and 8 weeks, anemic children ingested black dates with or without hulls had higher $(\mathrm{P} \leq$ $0.05)$ SI, SF and TS than positive control group, while TIBC had an opposite trend. The TIBC in black date groups was decreased by increasing the experiment period. Date without hulls group was more effective $(\mathrm{P} \leq 0.05)$ than date with hulls group in improving SI, SF, TS and TIBC with the exception of SF for 4 weeks which was simila $\left(\mathrm{P}^{\prime} 0.05\right)$ in the two groups. This observation might be due to the high fiber content in dates with hulls, which had a negative effect in iron absorption These results are in agreement with Abdel- Rahman et al., (2008) who reported that black dates improved the levels of $\mathrm{Hb}$, SI and SF in anemic Egyptian female's childbearing. Rosado et al. (2010) found that supplementation children (6-43 months) for 4 months with iron enhanced the levels of SI, SF and TIBC. Fortified milk consumption compared to consumption of control milk, resulted in an increase in mean body iron stores (SF) and a significant reduction in mean total iron binding capacity (Sazawal et al., 2010).

\section{CONCLUSION}

Finally it can be concluded that, iron from black dates with or without hulls is cheap, safe, and effective in improving hemoglobin levels and restoring iron stores to correct iron deficiency anemia.

\section{ACKNOWLEDGMENT}

We thank the staff at the orphanage for their cooperation and support

\section{1- Yield/vine:}

Data in Table (1) clearly show that spraying elusters of Early sweet grapevines with $\mathrm{GA}_{3}$ at 10 to $40 \mathrm{ppm}$ or Sitofex at 2.5 to $10 \mathrm{ppm}$ was significantly effective in improving the yield relative to the check treatment. The promotion on the yield was accompanied with increasing concentrations of each plant growth regulator. Using $\mathrm{GA}_{3}$ at 10 to 40 was significantly preferable than using Sitofex at 2.5 to $10 \mathrm{ppm}$ in improving the yield. A slight ane unsignificant promotion on the yield was attributed to increasing concentrations of $\mathrm{GA}_{3}$ from 20 to 40 ppm and Sitofex from 5 to $10 \mathrm{ppm}$. The maximum yield was produced on the vines that received one spray of $\mathrm{GA}_{3}$ at $40 \mathrm{ppm}$ but the best treatment from economical point of view was the application $\theta$ $\mathrm{GA}_{3}$-at $20 \mathrm{ppm}$ (since no measurable promotion on the yield was recorded between 20 and 40 ppm of $\left.\mathrm{GA}_{3}\right)$. Under such promised treatment, yield/ vine reached 13.6 and $14.0 \mathrm{~kg}$ during both seasons, respectively. The control vines produced 9.1 and 9.6 $\mathrm{kg}$ during 2013 and 2014 seasons, respectively. The percentage of increase on the yield due to applieation of $\mathrm{GA}_{3}$ at $20 \mathrm{ppm}$ over the check treatment reached 49.5 and $45.8 \%$ during both seasons, respectively. The beneficial effects of $\mathrm{GA}_{3}$ on the yield might be attributed to their positive action on increasing cluster weight. The promoting effects of $\mathrm{GA}_{3}$ - on the yield was supported by the results of Dimovska et al., (2011) and Abu-Zahra and Salameh (2012) on different grapevine evs.

The results regarding the beneficial effects of Sitofex on enhancing the yield are in harmony with those obtained by Juan et al. (2009); Abdel Fattah etal., (2010) and Al Obeed (2011).

\section{2-Harvesting date:}

It is clear from the data in Table (1) that all $\mathrm{GA}_{3}$ and Sitofex treatments had signifieantly delayed on the harvesting date of Early Sweet grapevines rather than the control treatment. The degree of delayness on harvesting date was correlated to the increase of the concentrations of both $\mathrm{GA}_{3}$ and Sitofex. Using $\mathrm{GA}_{3}$ significantly delayed harvesting date comparing with using Sitofex. Increasing concentrations of $\mathrm{GA}_{3}$ - from 20 to $40 \mathrm{ppm}$ and Sitofex form 5 to $10 \mathrm{ppm}$ failed to show significant delay on harvesting date. A considerable advancement on harvesting date was observed on untreated vines the great delay on harvesting date was observed on the vines that received $\mathrm{GA}_{3}$-at 40 pom-during both seasons. $\mathrm{GA}_{3}$ and Sitofex were shown by many authors to retard the release of ethylene and the disappearance of pigments such as chlorophylls and carotenoids and onest of maturity start. Also they were responsible for prolonging prematurity stages Nickell (1985). These results regarding the delaying effect of $\mathrm{GA}_{3}$-and Sitofex on harvesting date were in harmony with those obtained by Wassel et al., (2007), Kassem et al. (2011), Abu-Zahra and Salameh (2012) and Refaat et al. (2012).

\section{3-Cluster weight and dimensions}

It is evident from the data in Table (1) that treating clusters with $\mathrm{GA}_{3}$ at 10 to $40 \mathrm{ppm}$ or Sitofex at 2.5 to $10 \mathrm{ppm}$ was significantly accompanied with enhaneing weight, length and width of cluster relative to the control treatment. 
19. 
The promotion was significantly associated with increasing concentrations of $\mathrm{GA}_{3}$ and Sitofex. Using $\mathrm{GA}_{3}$ was significantly favourable than using Sitofex in this respect. The maximum values were recorded on the vine that of $\mathrm{GA}_{3}$ at 40 ppm. Meaningless promotion was detected with increasing concentrations of $\mathrm{GA}_{3}$ from 20 to $40 \mathrm{ppm}$ and Sitofex from 5 to $10 \mathrm{ppm}$. The untreated vines produced the minimum values during both seasens. The positive action of $\mathrm{GA}_{3}$-on cluster weight and dimensions might be attributed to its essential role en stimulating cell division and-entargement of 
cells, the water absorption and the biosynthesis of proteins which will lead to increase berry weight Dimorska al., (2011); Abu Zahra and Salameh (2012) and Dimovska et al., (2014).

The previous essential role of CPPU on cluster weight was attributed to its higher content of eytokinin when applied to plants (Nickell, 1985). 4-Shot berries $\%$ :

Data in Table (2) obviously reveal that percentrge of shot berries in the clusters of Early Sweet grapevines was significantly controlled with spraying $\mathrm{GA}_{3}$ at 10 to $40 \mathrm{ppm}$ or Sitofex at 2.5 to 10 ppm relative to the check treatment. Using $\mathrm{GA}_{3}$ was preferable than using Sitefex in redureing the percentages of shot berries. There was a gradua reduction on the percentage of shot berries with increasing concentrations of $\mathrm{GA}_{3}$ and Sitofex. There was a slight reduction on such unfavourable phenomenon with increasing concentrations of $\mathrm{GA}_{3}$ form 20 to $40 \mathrm{ppm}$ and Sitofex from 5 to $10 \mathrm{ppm}$ The minimum values of shot berries (7.3 and $6.9 \%$ during both seasons, respectively) were recorded on the clusters harvested from vines treated with $\mathrm{GA}_{3}$ at $40 \mathrm{ppm}$. The maximum values of shot berries $(12.0 \& 12.5 \%)$ during both seasons were recorded on the untreated vines during both seasons. The reducing effect of $\mathrm{GA}_{3}$ - on shot berries might be attributed to its important role on enhancing cel division and the biosynthesis of proteins Nickell, (1985). These results were supported by the result of wassel et al. (2007) and Abu-Zahra and Salameh (2012)

\section{5- Fruit quality:}

Data in Tables $(2,3$ \& 4) clearly show that spraying clusters with GA3 at 10 to 40 ppm of Sitofex at 2.5 to $10 \mathrm{ppm}$ significantly was accompanied with enhancing weight, longitudinal and-equatrial of berry, total acidity \%, proteins of and percentages of $\mathrm{P}, \mathrm{K}$ and $\mathrm{Mg}$ and T.S.S. \% reducing sugars \%, T.S.S. / acid and tota earotenoids relative to the check treatment. The effect either increase or decrease was associated with increasing concentrations of each auxin. Using $\mathrm{GA}_{3}$-significantly changed these parameters than tying Sitofex. A slight effect was recorded on these quality parameters with increasing concentrations $\theta$ $\mathrm{GA}_{3}$ from 20 to $40 \mathrm{ppm}$ and Sitofex from 5 to 10 ppm. From economical point of view, the bes results with regard to fruit quality were observed due to treating clusters with $\mathrm{GA}_{3}$ at $20 \mathrm{ppm}$. Untreated vines produced unfavourable effects on fruit quality. These results were true during both seasons. The effect of $\mathrm{GA}_{3}$ - 0 increasing berry weight and dimensions might be attributed to its effect in promoting cell division and enlargement of eells, water uptake and the biosynthesis of protein Nickell (1985). These results were in concordance with those obtained by Williams and Ayars (2005) and Dimorska et al., (2014)
The higher content of Sitofex from cytokinins strly reflected on enhancing cell division and the elongation of berries Nickell (1985). These result were in agreement with those obtained by AbuZahra (2013) and Retamales et al. (2015).

\section{CONCLUSION}

Treating Early Sweet orapevines once when the average berries reached $6 \mathrm{~mm}$ with $\mathrm{GA}_{3}$ at $20 \mathrm{ppm}$ was responsible for promoting yield and frut quality.

\section{REFERENCES}

Abdel-Rahman M K, Anein A A and Hussien A M (2008). Effect of Iron-Food Intake on Anaemia Indices; Hae-moglobin, Iron an Ferritin among Childbearing Egyptiap Females World Journal of Agricultural Sciences 4(1): 7-12.

Al Farsi M A and Lee C Y (2008). Nutritional and functional properties of dates: areview. Critical Reviews in Food Science and Nutrition 48: 877-887.

Al-Shahib W and Marshall R J (2003). The fruit of the date palm: its possible use as the best food for the future? International Journal of Food Sciences and Nutrition 54 (4): 247-259.

AOAC, (1990). Official Methods of Analysis, 15th Edition, Association of Official Analysis Chemists, Washington, D C R

Black RE, Morris SS and Bryce J (2003). Where and why are 10 million children dying ever year? Lancet 361: 2226-2234.

DRI (2003). Dietary reference intakes for energy, carbohydrate, fiber, fat, protein, calcium phosphorous, vitamin $\mathrm{D}$, thiamin, riboflavin, vitamin $C$, vitamin $E$, vitamin $A$, zinc and iron. Washington DC: National Academ Press, Food and Nutrition Board, Institute of Medicine.

El Gendy M S A (2000). Nutritional assessment for orphans at social welfare institution of Menoufia Governorate. M.SC. Thesis faculty of Home Economics Menoufia University Egypt.

El Mancy S M (2008). Studying the efficiency of dietary intervention among children suffering from iron deficiency anemia. M.SC. Thesis, Faculty of Home Economics Menoufia University Egypt.

El Shorbagey H F E (2012). The effect of some enhancing and inhibiting factors on non-hern iron absorption and haematogenip characteristics in rats. M.SC. Thesis, faculty of Home Economics Menoufia Universit Egypt. 
Falkingham M, Abdelhamid A, Curtis P, Fairweather-Tait S, Dye L and Hooper L (2010). The effects of oral iron supplementation on cognition in older children and adults: a systematic review and meta-analysis. Nutrition Journal 9: 4-13.

Gasche C, Lomer MC, Cavill I and Weiss G (2004). Iron, anaemia, and inflammatory bowel diseases. Gut 53: 1190-1197.

Hernández M, Sousa V, Villalpando S, Moreno A Montalvo I and López-Alarcón M (2006). Cooking and Fe Fortification Have Different Effects on Fe Bioavailability of Bread and Tortillas. Journal of the American College of Nutrition 25 (1): 20-25.

Hijar G, Aramburu A, Hurtado Y and Suárez (2015). Rice fortification to correct micronutrient deficiency in children 6-59 months old. Rev Panam Salud Publica 37(1) 52-58.

Hussein E H, Mohamed M S and Helal A H (2006). Nutritional status of orphans children living in orphanage at Shibin El- Kom city Egypt. Journal of Home Economics Menoufia University 16 (1): 31-46.

Karim K M R and zahid M K (2012). Nutritional status and dietary intake of the orphans: A case study in the ICH (Intervida Children Home) in Dhaka city in Bangladesh. Bangladesh Journal of Nutrition 24: 23-30

Lee R, Nieman D, (1996). Nutritronal Assessment 2nd Edition, McGraw - Hill Science/Engineering/Math, Mosby.

Mohamed A Y and Khamis A S (2004). Mineral ion content of the seeds of six cultivars of Bahraini date palm (Phoenix dactylifera). Journal of Agricultural and Food Chemistry 52: $6522-6525$.

National Institute of Nutrition. 1996. Nutritive values of local food, Cairo Egypt.

Rosado J L, González K E, Caamaño Md C, García O P, Preciado R and Odio M (2010). Efficacy of different strategies to treat anemia in children: a randomized clinical trial. Nutrition Journal 9: 40-49.

Santiage, P (2012). Ferrous versus ferric oral iron formulations for the treatment of iron deficiency: a clinical overview. The Scientific World Journal Article ID 846824, 5 pages doi:10.1100/2012/846824.

Sazawal S, Dhingra U, Dhingra P, Hiremath G, Sarkar A, Dutta Menon P and Vand Black R E (2010). Micronutrient Fortified Milk Improves Iron Status,Anemia and Growth among Children 1-4 Years: A Double
Masked, Randomized, Controlled Trial. PLoS ONE J 5(8): e12167-12174

Soliman AT, Al Dabbagh MM, Habboub AH, Adel A, Humaidy NA and Abushahin A (2009). Linear growth in children with iron deficiency anemia before and after treatment. J Trop Pediatr 55: 324-327

Tang N, Zhu Y and Zhuang H (2015). Antioxidant and anti-anemia activity of heme iron obtained from bovine hemoglobin. Food Sci Biotechnol 24(2): 635-642.

Yurdakök K, Temiz F, Yalçin SS and Gümrük F (2004). Efficacy of daily and weekly iron supplementation on iron status in exclusively breast-fed infants. J Pediatr Hematol Oncol 26(5): 284-288.

WHO (2007). Growth standards (Http://www.who.int/childgrowth/ standards/bmi for age/en/index html) Accessed Sep 09/2007\& Nov OS/2010.

Abdel-Fattah, M.E. Amen, K.A.; Alaa, A.B. and Eman, A.A. (2010). Effect of berry thinning, CPPU spraying and pinching on cluster and berry quality of two grapevine cultivars. Assiut J. of Agric. Sci., 40(4): 92-107.

Abu-Zahra, T.R. (2013). Effect of plant hormones application methods on fruit quality of Superior seedless grape. Bioscience Biotechnology Research Asia Vol. 10(2): 527.531.

Abu-Zahra, T.R. and Salameh, N. (2012). Influence of Gibebrellic acid and cane girdling on berry size of Black Magic grape cultivar. Middle East Journal of Scientific Research-11(6): 718-722.

Al-Obeed, R.S. (2011). Enhancing the shelf life and storage ability of Flame seedless grapevine by agrochemicals preharvest foliar applications. Middle East Journal of Scientific Research 8 (2): 319-327.

Association of Offieial Agrieultural Chemists (A.O.A.C.) (2000). Official Methods of Analysis (A.O.A.C), 12 ${ }^{\text {th }}$ Ed., Benjamin Franklin Station, Washington D.C., U.S.A. pр. 490.510.

Dimovska, V.; Ivanova, V.; llieva, F. and Sofijanova, E. (2011). Influence of bioregulator gibberellic acid on some technological characteristics of cluster and berry from some seedless grape varieties. Journal of Agric. Science and technology BI 10741058.

Dimovska, V.; Petropulos, V.I.; Salamovska, A. and Hlieva, F. (2014). Flame seedless grape wariety (Vitis vinifera- L.) and different concentration of gibberellic acid (GA3). Bulgarian Journal of Agric. Sci., 20 (No.1) 137142 . 
Dokeozlian, N.K. (2001). Gibberellic acid applied at blom reduces friitset andimprosize"Crimsen seelless" Table grapes Hort.science 36(4): 706-709

Guiseppe; F.; Andream, M.; Guiseppe, N. Carmela, P. Angela, M.; Isabella, C. Piero, M Mariangela, V. and Vito, G. (2014). Girdling, Gibberellic acid, and forchlorfenuron effect yield, quality and metabolic profile of table grape ev. Italia. Am. J. Enel. Vitic. 65.3.

Hiscox, A. and Isralstam B. (1979). Method for the extraction of chlorophylls from leaf tissue without maceration. Can. J. Bet. 57: 1332 1334.

Juan, P.Z.; Bernardo, A.L. and Paulina, N. (2009). Preharvest applications of growth regulators and their effect on pestharvest quality of table grapes during cold storage. Postharvest Biology and technology 51. 183-192.

Kassem, H.A.; Al-Obeed, R.S. and Soliman, S. S. (2011). Improving yield, quality and profitability of Flame seedless grapevine grown under arid environmental by growth regulators preharvest applications. Middle East Journal of Seientific research 8 (1): 165 172.

Lane, J $\mathrm{H}$ and Eynon, L (1965). Determination of reducing sugars by means of Fehlings solution with methylene blue as indicator A.O.AC. Washington D.C.U.S.A. pp. 490 510.

Leopold, A. C. (1964). Plant growth and development. pp. 133-143.TATA McGraw Hill publishing Comp. LTD. Bombay New Delhi.

Marzouk, H.A. and Kassem, H.A (2011). Improving yield, quality and shelfe life of Thempsen seedless grapevine by preharvest foliar application. Scientia Horticulruea 130: 425 430
Mead, R.; Currnow, R. N. and Harted, A. M. (1993). Statistical Biolegy. 2"d Ed. Methods if Agriculture and Experimental and Hall, London pp. 10-20.

Nickell, L.G. (1985). New plant growth regulater increase grape size. Proc. Plant growth red. Soc. of Am. 12.1-7.

Refaat, S.S.E.; Ghada, Sh.Sh. and Ola, A.A.(2012) Effect of foliar spraying with gibberllic acil and/ or sitofex on bud behaviour, vegetative growth, yield and cluster quality of Thompson seedless grapevines. Journal of Ameriean Seience, 8 (5):99:21 34

Retamales, J.; Bangerth, F. Cooper, T. and Callejar R. (2015). Effect of CPPU and GA3 on frut quality of Sultanina table grape. Ishs Acta Hoerticulturae 394: plant Bioregulators in Horticulture.

Wassel, A.H.; Abdel Hameed, M.; Gobara, A and attia, M. (2007). Effect of some micronuitrients, gibberellic acid and ascorbic acid on growth, yield and quality of white Banaty seedless grapevines. African Crop Science Conference Proceeding Vol. 8 . 547-553.

Weaver, R. J.(1976). Grape Growing . A Wile Interscience Puplication John Wiley \& Davis New York. London. Sydney. Tronto. Pp 160 175.

Wilde, S. A.; Corey, R. B.; Lyer, I. G. and Voigt, $d$ K. (1985). Soil and Plant Analysis for Trep Culture. $3^{\text {rd }}$-Oxford \& IBH publishing $\mathrm{Co}$, New Delhi, pp. $1-218$.

Williams, L.E. and Ayars, J.E. (2005). Water use of Thompson seedless grapevines as affected b the application of Gibberellic acid $\left(\mathrm{GA}_{3}\right)$ an trunk girdling practices to increasing Berr size. Agriculture and Forest Meterology, 129. $85-94$ 


\section{الملذص العربى}

تأثير البلح الاسود علي انيميا نقص الحديد لاطفال الملاجئ

هبة عز الدين يوسف وعبير أحمد خضر

قسم التغذية و علوم التغذية بكلية الاقتصاد المنزلي جامعة المنوفية، شبين الكوم، مصر حصر

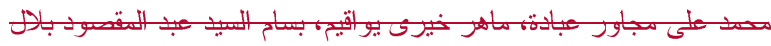

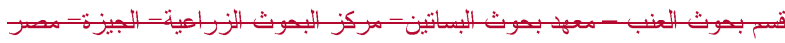

تمثل أنيميا نقص الحديد مشكلة صحية عامة رئيسية، خاصة عند الرضع والأطفال الصغار و النساء الحوامـلـ.

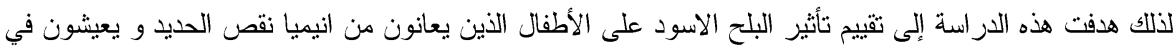

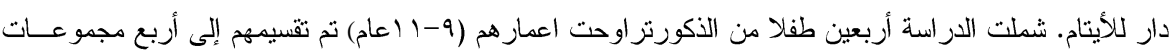

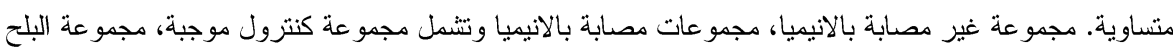

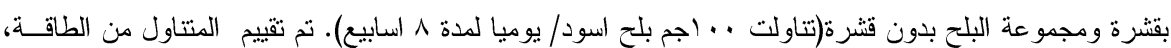


البروتين، الكربو هيدرات، الدهون، الأليان، الفيتامينات و المعادن لكلا من المجموعة المصابة والغير مصابة بالانيميا

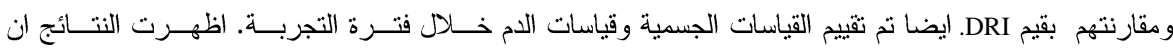
المجموعة المصابة بالانيميا لم يحصلوا علي كمية كافية من البروتين بينما الطاقة والألياف كانت مماثلة تقريبا لقيم

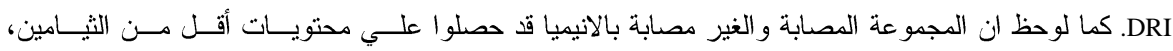

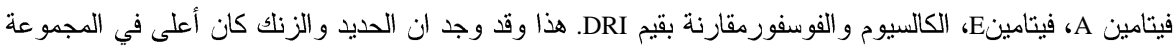

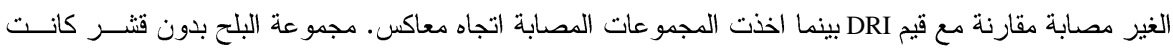

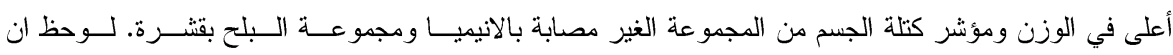

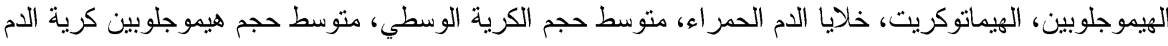

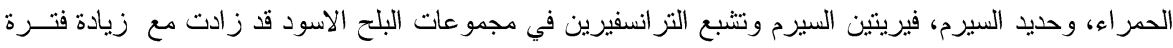

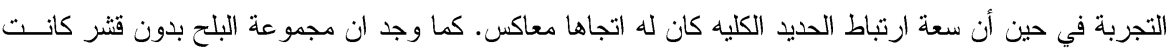

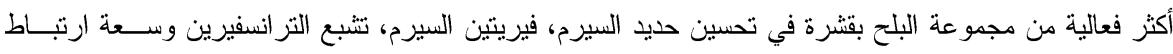
الحديد الكليه.

الكلمات الاليلية: أطفال ملاجئ، انيميا، هيموجلوبين و المتناول الغذائي

Formatted: Font: $10 \mathrm{pt}$, Not Bold, Complex Script Font: Times New Roman, Not Bold 